\title{
Moderating effect of Firm Characteristics in the Financing Diversification - Performance nexus among Credit Unions in Kakamega County, Kenya
}

\author{
Jonathan Mwau Mulwa, PhD, MKIM \\ Murang'a University of Technology, Kenya \\ jmwau@yahoo.com
}

\begin{abstract}
The last two decades has seen a lot of creativity and diversity in the funding strategies pursued by credit unions as a result of financial sector liberalization and competitive pressure in the financial system. Research has shown that this diversification is both beneficial and hurting at the same time. However, firm characteristics have not mostly been factored in the diversification - performance analysis though studies in other sectors underline their importance. This therefore prompted this study to analyze the moderation effect that firm characteristics - specifically age, size, members' occupation and management structure of credit unions - could have on the relationship between diversification and performance of credit unions in Kenya. The study used a correlation analysis approach on a data set of sixteen credit unions in Kakamega County and found that whereas financing diversification had a significantly positive relationship with credit union performance; credit union size and members' occupation significantly improved this relationship while age and management structure significant suppressed the relationship.
\end{abstract}

\section{Indexing terms/Keywords}

Firm characteristics, Financing diversification, Performance, Credit Unions

\section{Academic Discipline And Sub-Disciplines}

Business: Financial Intermediation

SUBJECT CLASSIFICATION

Business Subject Classification

TYPE (METHOD/APPROACH)

Correlational analysis approach

\section{Introduction}

From their very inception, credit unions have existed for purposes of promoting thrift among its members and creating a source of credit for provident and productive purposes (Froman 1935; Smith 1984; Tache, 2006; KUSCCO, 2011). To achieve this motive, credit unions have traditionally raised funds for their operations from their members' savings until recently when liberalization of the industry allowed them to explore other means of raising funds (Bellco credit union, 2009). A lot of research has been carried out on the benefits, or lack thereof, of this diversification on the performance outcomes of the credit unions, notable examples being Esho et al., (2005), Goddard et al., (2008), Mulwa (2013) and Mathuva (2016). However, very little has been said about the diversification outcomes in the contest of credit union characteristics. While research has identified some firm characteristics as critical determinants of credit union performance (e.g. Mathuva, 2016), it is not clear how these factors would influence the diversification - performance relationship in credit unions. In this regard therefore, this study sought to explore the effect that firm characteristics, specifically age, size, members' occupation and management structure, of a credit union may have on the relationship between financing diversification and performance of the credit union using a correlational approach, based on a set of sixteen credit unions in Kakamega county. To answer this question, the study set the following null hypothesis:

$\mathrm{H}_{0}$ : firm characteristics do not moderate the relationship between financing diversification and the performance of credit unions

\section{Credit Unions Characteristics}

Firm characteristic play a very important role in shaping the performance of any organization; credit unions included. Some of the features characteristic of credit unions include; the members' occupation, the credit union's management structure, the size, and the age of the credit union. A defining feature of credit unions is the common bond membership which emphasizes the relationship between the form of organization and the constituency from which it draws its membership (Lune and Martinez, 1999). The common bond membership usually limits the membership to a similar professional or occupational background. This single occupational affiliation prevents a credit union from diversifying risks (Mishkin and Eakins, 2007) and consequently has a bearing on the performance of the credit union since the performance is limited by the liquidity characteristics of the members. CUNA (2005) contend that credit unions are all about their members; they raise deposits from members and offer loans to members only and not to the general public. It is intuitively plausible that risks of economic instability experienced by the common employer may affect the safety and performance of the occupational credit union which serves its labour force (Patin and McNiel, 1996). 

Another credit union characteristic is management structure (also known as organizational structure) which is the method by which the staff, departments, divisions and regions work and interact with one another (Walters, 2011). It is the division of authority, responsibility, and duties among members of an organization. Management structure may be decentralized (flat) or centralized (hierarchical) and each of the structures has a bearing on the performance of an organization. Flat management structure promotes a decentralized decision-making process, which increases staff involvement and is achieved by very few or no management layers between front-line workers and the company's leadership. This promotes performance by reducing the amount of time taken in decision making and for credit unions reduces the loan application turnaround time. Short turnaround time is important to the performance of a credit union because if it cannot provide a loan as and when needed by a member, then it is failing in its duty of service to members (WOCCU and FSD, 2008).

The size and age of the credit union are other organizational factors that affect not only the relationship between financing diversification and credit union performance but can also affect the performance of the credit union. The size and age of a firm comes with it a chain of performance enhancing characteristics acquired through learning and growth. Large and old credit unions enjoy a better performance because of their large membership base and the potential of accumulating large financial reserves. This was confirmed by CUNA (2005) who contends that because of their size and efficiency, large credit unions are often more able to provide the benefits of the cooperative to members, such as lower loan rates and fees and higher dividend rates. Larger credit unions are also more able to offer special programs benefiting low- and moderateincome households. A large credit union may be more likely to offer a broader array of services, and to be a greater presence in a local community. In their study entitled "does fund size erode mutual fund performance?" Chen et al., (2004) however, contradicts this position. They argued that fund size erodes performance and they attributed this to liquidity and organizational diseconomies which increase as the size increases. This may however not be the situation for credit unions since they are characteristically different from mutual funds.

Research on the moderating influence that firm characteristics have on strategy-outcome relationships is advanced in other financial institutions but remain scanty for credit unions. However, studies involving credit unions have at least shed some light on firm size and how it affects not only the credit unions performance but also the performance outcomes of the various strategies adopted by these credit unions. For instance, while investigating the effect of revenue diversification on financial performance, Goddard et al., (2008) reported a negative effect of diversification on return measures for all but the largest credit unions. As such, they concluded that small credit unions should eschew diversification as this was not beneficial to them whereas large ones should be encouraged to pursue new opportunities around their expertise. This shows that size had a beneficial moderation effect on diversification - performance relationships for large credit unions.

Esho et al., (2005) also reported a positive moderation effect of size on diversification performance relationship. While investigating the effect of diversification, fee generating activities and increased transaction fees charged on existing products and diversification into in to residential mortgages, they reported that more diversified credit unions had lower risk and return. Similarly, credit unions that increased their transaction fees had increased risks and lower returns while those which diversified into residential mortgages had reduced risks and returns. However, their study reported scale related economies with risk decreasing and returns increasing with credit union size.

Contrary to Goddard Goddard et al., (2008) and Esho et al., (2005), Mathuva (2016) reported a negative moderation effect of size on the diversification - performance relationship in Kenyan credit unions. He reported that that revenue diversification was beneficial to smaller size Saccos and identified size as a determinant factor in Sacco performance. Mathuva (op cit) recommended a cautious diversification strategy as a Sacco grew since diversification was less beneficial for large Saccos. In banks, Mercieca et al., (2007) reported that earnings diversification within or across sectors had no impact on small banks profitability while they observed a negative relation between non-interest revenue and profitability discouraging small banks from diversifying into non-core activities. The size variable was relevant for the performance with the results showing that larger banks within the sample performed better.

While analyzing the determinants of credit union takeover using data obtained from NCUA over a six year period, (Sant et al., 2015) identified several factors critical to premerger credit union performance. Notably, is a decline of loan portfolio and net interest margin as a proportion of deposits and an increase in operating expenses which they attributed to poor management ability and lack of economies of scale associated with small credit unions. This implies that management ability or structure as well as the size of the credit union were critical to the performance of any credit union. These literature streams at least point to the moderation effect of firm characteristics on diversification - performance relationship and which this study sought to analyze.

\section{Methodology}

As proposed by Baron and Kenny (1986), a correlational analysis approach was used in this study to analyze the moderation effects of firm characteristics. Within a correlational analysis framework, the moderator is a third variable that affects a zero order correlation between two other variables (Baron and Kenny, 1986). Precisely moderation occurs when the causal relation between two variables changes as a function of the moderator function. Whisman and McClelland (2005) proposes three approaches to testing moderation effects namely; testing whether the increment in the squared multiple correlation $\left(\Delta R^{2}\right)$ is significantly greater than zero or; testing whether the slope coefficient of the product term of the moderator and independent variable in a regression equation with dependent variable differs from zero or; testing whether the partial correlation between the independent-moderator product and dependent variable when controlling for the moderator and independent variable is differs from zero. A simplified approach of the third way of checking moderation and which was applied in this study is to check whether the partial (first order) correlation of dependent and independent variable when controlling for the moderator is different from the zero order correlation between dependent
2989 | P a g e
council for Innovative Research
October 2016
w w w. ci r world. com 
International Journal of Management and Information Technology and independent variable. Since this was a follow-up on an earlier study by Mulwa (2013), study was based on a data set from sixteen credit unions collected from a key informant in 2011. The variables were measured using interval and Likerttype scales because of their superior information values and handiness in respondent centered studies (Kothari, 2010) and operationalized as shown in table 1 below.

Table 1: Operationalization of variables

\begin{tabular}{|c|c|c|c|}
\hline \multirow{2}{*}{\multicolumn{2}{|c|}{$\begin{array}{l}\text { Variable } \\
\text { Credit union performance }\end{array}$}} & Operationalization & \multirow{2}{*}{$\begin{array}{l}\text { Indicator } \\
\text { Proportion of loans to share capital; } \\
\text { successful loan applications; cost } \\
\text { of loans; application turnaround } \\
\text { time }\end{array}$} \\
\hline & & $\begin{array}{l}\text { Provision of easily accessible } \\
\text { consumer credit facilities to } \\
\text { members at fair cost }\end{array}$ & \\
\hline \multicolumn{2}{|c|}{ Financing Diversification } & $\begin{array}{l}\text { Utilization of variant sources to raise } \\
\text { funds by a credit union }\end{array}$ & $\begin{array}{l}\text { Share capital; deposit facilities; } \\
\text { capital reserves; investment } \\
\text { incomes; fees from services }\end{array}$ \\
\hline \multirow{4}{*}{ 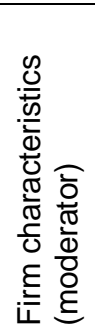 } & Age & $\begin{array}{l}\text { For how long has the credit union } \\
\text { operated }\end{array}$ & Years in operation \\
\hline & Size of credit union & Stability of members' occupation & $\begin{array}{l}\text { Income stability; consistency of } \\
\text { savings }\end{array}$ \\
\hline & Members' occupation & How big the credit union is & Number of members \\
\hline & Management structure & $\begin{array}{l}\text { Configuration of decision making } \\
\text { units }\end{array}$ & Extent of centralization \\
\hline
\end{tabular}

\section{Results and Discussions}

The firm characteristics which were the moderating variables in this study included the members' occupation; management structure; age; and the size of the credit union. Table 2 below presents the correlation results for the organizational factors. A statistically significant negation correlation was observed between a credit union's management structure and its members' occupation. This suggests that as the members' occupation becomes more stable and secure; the credit union adopts a more centralized management structure and moves away from the decentralized management which is characteristic of unstable members' occupation. A decentralized management structure is more suitable for a credit union whose members' occupation is not stable in order to reduce the decision time and ensure easy and quick access of services by members considering their liquidity characteristics (CUNA, 2005). This is consistent with the argument by WOCCU and FSD (2008) that short decision turnaround time is important to the performance of a credit union. Notably, all the correlation coefficients were below the 0.8 multi-collinearity threshold suggested Field (2009) and therefore there was no problem of multi-collinearity in the predictor (moderator) variables. This is ideal for a unique least squares solution to a regression analysis to be computed (Field, 2009; Belsley et al., 1980; Slinker and Glantz, 1985).

Table 2: Correlation results for firm characteristics

\begin{tabular}{lcccc}
\hline \multicolumn{1}{c}{ Indicators } & [1] & [2] & [4] & [4] \\
\hline [1] Age & 1 & & & \\
[2] Members' Occupation & .438 & 1 & & \\
[3] Size & .344 & -.070 & 1 & \\
[4] Management structure & .068 & $-.653\left(^{*}\right)$ & -.307 & 1 \\
\hline
\end{tabular}

${ }^{*}$ Correlation is significant at the 0.05 level (2-tailed).

Source: Research data, 2016

\subsection{Moderating role of firm characteristics on the relationship between financing diversification and performance}

The main objective of this paper was to establish whether firm characteristics had any moderating effect on the relationship between financing diversification and performance of credit unions. To achieve this, the study had set out the following hypothesis:

$\mathrm{H}_{0}$ : firm characteristics do not moderate the relationship between financing diversification and the performance of credit unions

Partial correlation analysis was used to test the hypothesis. The researcher correlated the mean of financing diversification against the mean of Credit union performance without factoring the organizational factors to obtain the zero order
2990 | P a g e
council for Innovative Research 

correlation coefficient $\left(r_{x y}\right)$ and then repeating the same process with every organizational factor as a control variable to obtain the partial correlation coefficients. The hypothesis test was set such that the null hypothesis was rejected if $r_{x y . z 1}=r_{x y . z 2}=\ldots=r_{x y . z n} \neq r_{x y}$ otherwise the null hypothesis would be accepted rejected. The results are presented in table 3 . The zero order correlation results (table $3 a$ ) of credit union performance and financing diversification indicate that performance is significantly correlated to financing diversification. This confirms the results by Mulwa (2013), using a linear regression model on a similar data set, that financing diversification significantly improved credit unions' performance $(\beta=0.398$, Prob. $=0.011$ and $F=8.717$, Prob.=0.011).

As pertains the moderation, the results the first order partial correlation results (table $3 b$ ) indicate that Age of the credit union and its management structure have a significantly negative moderating effect $\left(r_{x y . z}=0.638, p-v a l u e=0.014\right.$ and $r_{x y . z}=$ $0.671, p$-value $=0.012$ respectively). This implies that the presence of age and management structure in the correlation model suppresses or weakens the earlier strong relationship between financing diversification and credit union performance. This confirms the findings by Elyasiani and Wang (2012) among banks that diversification reduced efficiency especially for young ones since they lacked the first mover advantages in the market. However, the credit union Size had a moderately positive and significant moderating effect $\left(r_{x y . z}=0.613, p\right.$-value $\left.=0.034\right)$ with the occupation of members' having a slightly positive but significant moderation effect $\left(r_{x y . z}=0.628, p\right.$-value $\left.=0.029\right)$ which implied that a larger credit union whose members had a more stable occupation benefited a lot from pursuing variant financing sources that would otherwise be the case. The finding on size confirms the findings by Mercieca et al., (2007), Bashir (1999), Dermiguc-Kunt and Huizinga (2012) and Garmbarcorta et al., (2014) that large financial institutions enjoyed better diversification outcomes than smaller ones. CUNA (2005) also reported that large credit unions were more likely to enjoy better performances. As argued by Porter (1980) large firms are able to erect barriers which play out competitors and therefore command better returns as the absolute volume per period increases.

Important though, as shown in table $3(b)$, none of the $r_{x y . z i}$ was equal to $r_{x y}\left(r_{x y . z 1} \neq r_{x y . z 2} \neq \ldots . . \neq r_{x y . z n} \neq 0.634\right)$. Additionally all the first order partial correlation coefficients were significant at five percent significant level (prob. $<0.05$ ) and therefore the study rejected the null hypothesis that firm characteristics do not moderate the relationship between financing diversification and the performance of credit unions. As such, it can be concluded that that firm characteristics moderate the relationship between financing diversification and the performance of credit unions.

Table 3: Zero and first order correlation results of diversification, performance and firm characteristics

a. Results of zero order correlation of financing diversification and Credit union performance

\begin{tabular}{lcc}
\hline & {$[1]$} & {$[2]$} \\
\hline [1] Performance & 1 & $.634^{*}$ \\
[2] Financing diversification & $.634^{*}$ & 1 \\
\hline
\end{tabular}

* Correlation is significant at the 0.05 level (2-tailed).

b. Results of first order partial correlation of financing diversification and performance with firm characteristics

\begin{tabular}{lccl}
\hline \multicolumn{1}{c}{ Moderator $\left(\mathrm{z}_{\mathrm{i}}\right)$} & $\begin{array}{c}\text { First order partial } \\
\text { correlation }\left(\mathrm{r}_{\mathrm{xy} . \mathrm{zi}}\right)\end{array}$ & Prob. $\left(\mathrm{r}_{\mathrm{xy} . \mathrm{zi}}\right)$ & $\begin{array}{c}\text { Moderation effect } \\
\left.\text { (compared to } \mathrm{r}_{\mathrm{xy}}=0.634\right)\end{array}$ \\
\hline Age & .638 & .014 & Slightly Negative \\
Size & .613 & .034 & Moderately positive \\
Members' occupation & .628 & .029 & Slightly positive \\
Management structure & .671 & .012 & Moderately negative \\
\hline
\end{tabular}

\section{Source: Research data, 2016}

\section{Conclusions}

Do firm characteristics moderate the relationship between financing diversification and performance of credit unions? This paper finds significant variances in zero order correlations between financing diversification with performance and the first order partial correlations of the same variables when various firm characteristics are controlled. This implies that firm characteristics moderate the relationship between financing diversification and performance of credit unions. However, the direction and magnitudes of moderation vary across the various firm characteristics with Age and Management structure of a credit union having a negative moderation effect while Size and Members' occupation had a positive moderation effect. Based on these findings, this study recommends that credit unions put in place measures to increase their membership because the size of a diversifying Sacco has the largest positive moderating effect on the relationship between financing diversification and Sacco performance. Additionally, credit unions should adopt more decentralized management structure to reduce the negative moderating effects associated with centralized and rigid management structures characteristic of credit unions
2991 | P a g e
council for Innovative Research 
International Journal of Management and Information Technology

\section{REFERENCES}

[1] Baron R.M. and Kenny D. A., (1986). The Moderator - Mediator Variable Distinction in Social Psychological Research: Conceptual, Strategic and Statistical Considerations. Journal of Personality and Social Psychology, Vol. 51(6), Pp. 1173-1182

[2] Bashir M.A., (1999). Risk and Profitability Measures in Islamic Banks: The Case of Two Sudanese Banks, Islamic Economic Studies, Vol. 6(2), Pp.1-24

[3] Bellco credit union, (2009) (hhtp://faqs.bellco.org/bellco/consumer/kbdetail.asp?kbid=308)

[4] Belsley, D.A., Kuh, E., and Welsch, R.E., (1980). Regression diagnostics: Identifying influential data and sources of collinearity. New York, NY: John Wiley \& Sons

[5] Chen J., Hong H., Huang M., and Kubik J. (2004). Does fund size erode mutual fund performance? The role of liquidity and organization, The American Economic Review, Vol. 94(5)

[6] Credit Union National Association - CUNA (2005). Size doesn't matter in a credit union being a credit union, Wisconsin: Madison, (http://www.ncleague.org/www/upload/CUNA_CU_Size.pdf)

[7] Demirguc-Kunt A. and Huizinga H. (2012). Do we need big banks? Evidence on performance, strategy and market discipline, Bank for International Settlements (BIS) Seminar paper (http://www.bis.org/bcbs/events/bhbibe/demirguc.pdf)

[8] Elyasiani E. and Wang Y. (2012). Bank holding company diversification and production efficiency, Applied Financial Economics, Routledge: Taylor and Francis Group, Vol. 22(17), pp. 1409-1428

[9] Esho N., Kofman P. and Sharpe I.G. (2005). Diversification, Fee Income, and Credit Union Risk, Journal of Financial Services Research, Vol. 27(3), Pp. 259-281

[10] Field A., (2009). Discovering statistics using SPSS for windows, (3 $3^{\text {rd }}$ ed.). London: SAGE Publications

[11] Froman L. (1935). Credit Unions, The Journal of Business of the University of Chicago, Vol. 8(4), Pp. 338-344

[12] Gambacorta L., Scatigna M., and Yang J., (2014), Diversification and bank profitability: a nonlinear approach, Applied Economics Letters, Routledge: Taylor and Francis Group, Vol. 21(6), Pp. 438-441

[13] Goddard J., McKillop D., and Wilson J.O.S. (2008). The diversification and Financial Performance of US credit Unions. Journal of Banking and Finance, Vol. 32(9), Pp. 1836-1849

[14] Kariuki P.W., Ngugi P.K. and Muturi W.M. (2016). Income diversification and Intermediation efficiency: Evidence from deposit taking Sacco societies in Kenya. Research Journal of Finance and Accounting, Vol. 7(10), Pp. 17-26

[15] Kenya Union of Savings and Credit Cooperatives - KUSCCO, (2011) (http://www.kuscco.com/index.php?option=com_content\&task=view\&id=9\&ltemid=12

[16] Kothari C.R., (2010). Research Methodology; Methods and Techniques. Second Revised Edition, New Delhi: New age international $(P)$ Ltd. Publishers, New Delhi

[17] Lune H., and Martinez M. (1999). Old Structures, New Relations: How Community Development Credit Unions Define Organizational Boundaries. Sociological Forum, Vol. 14, No. 4, December, pp. 609-634

[18] Mathuva, D. (2016). Revenue diversification and Financial Performance of savings and credit co-operatives in Kenya, Journal of Co-operative Organization and Management, Vol. 4(1), 1-12

[19] Mercieca S., Schaeck K., and Wolfe, S. (2007). Small European Banks: Benefits from Diversification? Journal of Banking and Finance, Vol. 31 (7), Pp. 1975-1998

[20] Mishkin S.F., and Eakins S.G. (2007). Financial Markets + Institutions; Low Price Edition, $5^{\text {th }}$ Ed., Delhi: Dorling Kindersley (India) Pvt. Ltd.

[21] Mulwa J.M., (2013). Does Financing Diversification Matter? An evaluation of the Performance of Savings and Credit Cooperative Societies; A case of Kakamega County, Kenya, International Journal of Management \& Information Technology, Vol. 4(3), Pp. 324-333

[22] Patin R.P. Jnr. and McNiel D.W. (1996). Credit union safety and parent organization employment stability, Journal of financial and strategic decisions, Vol. 9(1)

[23] Porter, M. E. (1980). Competitive Strategy Techniques for Analyzing Industries and Competitors, The Free Press: New York

[24] Sant R.R., and Carter S.B. (2015). Acquired Credit Unions: Drivers of Takeover, International Journal of Business and Social Research, Vol. 5(8), Pp. 18-33

[25] Slinker B.K. and Glantz S.A., (1985). Multiple regression for physiological data analysis: the problem of multicollinearity. American Journal of Physiology - Regulatory, Integrative and Comparative Physiology, Vol. 249(1) 
International Journal of Management and Information Technology

[26] Smith D.J. (1984). A Theoretic Framework for the Analysis of Credit Union decision making, The Journal of Finance, vol. Xxxix (4)

[27] Tache G.M., (2006). Sustainable Sacco development, Rural Savings Promotion\& Enhancement of Enterprise Development (Rural SPEED), USAID/Uganda (http://pdf.usaid.gov/pdf_docs/PNADK962.pdf)

[28] Walters M.T., (2011). Organizational Management - Management Structure, Ezine Articles (http://EzineArticles.com/?exprt=MarkThomasWalters)

[29] Whisman M.A. and McClelland G.H., (2005). Designing, Testing, and Interpreting Interactions and Moderator Effects in Family Research. Journal of Family Psychology, Vol. 19(1), Pp. 111-120

[30] World Council of Credit Unions (WOCCU) and FSD Kenya, (2008). Institutional Capital as Bulwark for a Rainy Day, SACCO CAP News, Newsletter of WOCCU/FSD Sacco CAP Project, Issue 3 (http://www.kenyasacconet.org/docs/issue3.pdf)

\section{Author' biography}

Dr. Jonathan Mwau Mulwa is a Lecturer in Murang'a University of Technology - Kenya. He holds a Ph.D, and MBA in Finance and BBM in Finance and Banking. He as told Finance, Accounting and Management Science courses and supervised students research at university level for over six years as assistant lecturer in Masinde Muliro University of Science and Technology and Current a lecturer in Murang'a University of Technology. Dr. Mwau has research interests in investments, financial intermediation, corporate governance and financial deepening where he has published in various refereed journals. He is a full member of the Kenya Institute of Management (MKIM), a professional development institute in Kenya.

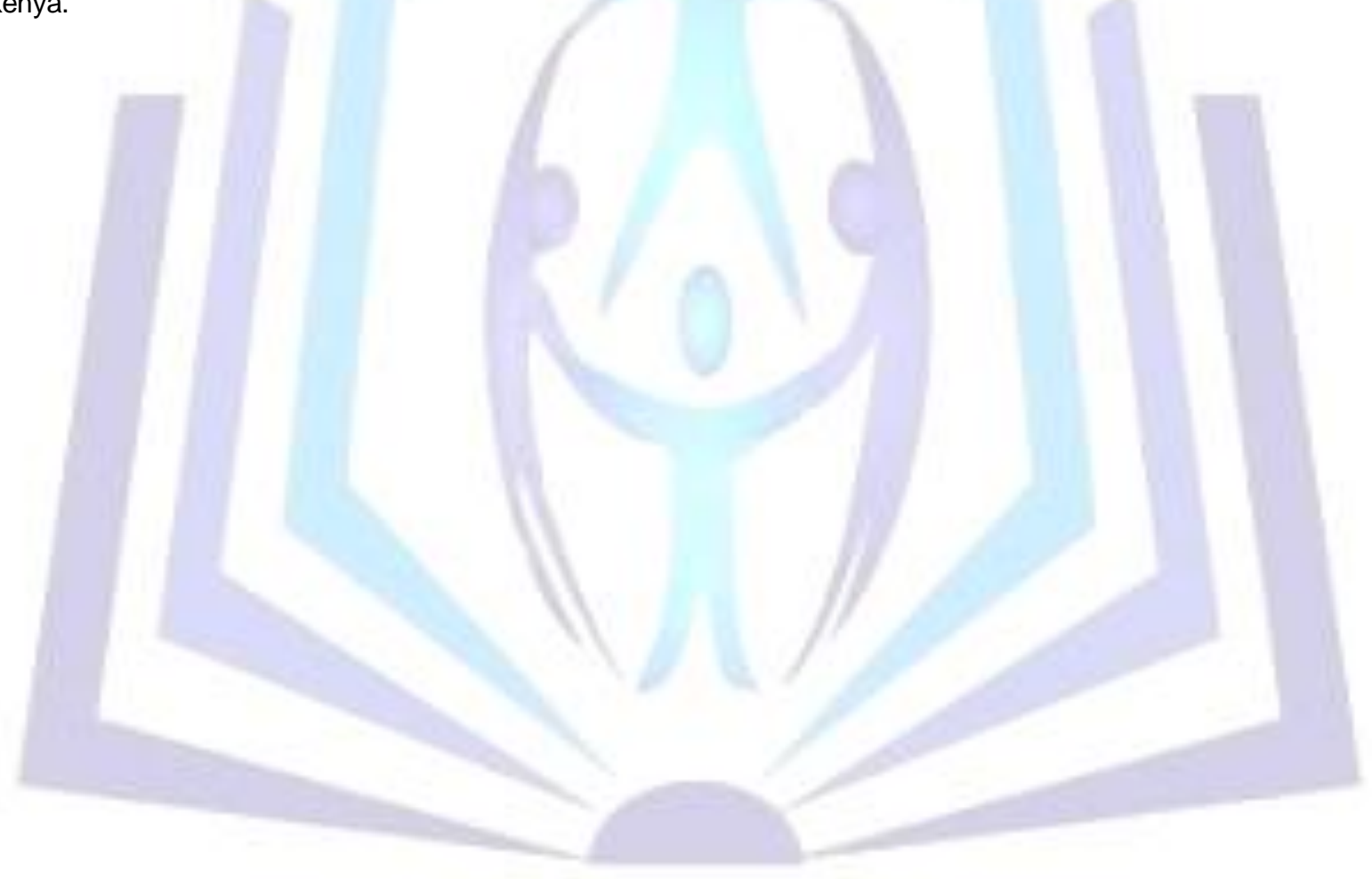

